Jennifer Gray, Culinary Diplomacy's Role in the Immigrant Experience. Fiction and Memoirs of Middle Eastern Women

Sophie-Anne Sauvegrain

\title{
C OpenEdition
}

Journals

Electronic version

URL: https://journals.openedition.org/ces/10379

DOI: $10.4000 /$ ces. 10379

ISSN: 2534-6695

Publisher

SEPC (Société d'études des pays du Commonwealth)

Electronic reference

Sophie-Anne Sauvegrain, "Jennifer Gray, Culinary Diplomacy's Role in the Immigrant Experience. Fiction and Memoirs of Middle Eastern Women", Commonwealth Essays and Studies [Online], 44.1 | 2021, Online since 15 January 2022, connection on 03 February 2022. URL: http://journals.openedition.org/ces/ 10379 ; DOl: https://doi.org/10.4000/ces.10379

This text was automatically generated on 3 February 2022.

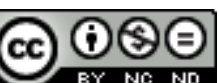

Commonwealth Essays and Studies is licensed under a Licence Creative Commons Attribution - Pas d'Utilisation Commerciale - Pas de Modification 4.0 International. 


\title{
Jennifer Gray, Culinary Diplomacy's Role in the Immigrant Experience. Fiction and Memoirs of Middle Eastern Women
}

\author{
Sophie-Anne Sauvegrain
}

\section{REFERENCES}

Jennifer Gray. Culinary Diplomacy's Role in the Immigrant Experience. Fiction and Memoirs of Middle Eastern Women. Lanham: Lexington Books, 2021. 144 p. ISBN: 9781793627339. $£ 90$

1 Following the example of Claude Levi Strauss, who explained in Mythologiques III. L'origine des manières de table (1968) how the cuisine of a society is a language in which it unconsciously translates its structure, Jennifer Gray invites us to listen to what the kitchen can express and convey, especially in the case of the encounter with other and distant people. She situates her work in relation with Sarah Dune's 1994 PhD Dissertation "The Foods We Read and the Words We Eat: Four Approaches to the Language of Food in Fiction and Nonfiction" and mobilizes the notion of culinary diplomacy, borrowed from Sam Chapple-Sokol.

2 With finesse and conviction, Gray reveals the role, effects, and scope of culinary diplomacy, with different scales of analysis in mind, from the geo-political to the social spheres of every-day life and advocates the importance of the latter, in the sense that "citizen culinary diplomacy" occurs at local levels in which people come together to interact and learn about cultures different from their own.

3 This book is dedicated to the illustration of this concept, through the presentation of multi-site situations, originating from postcolonial literature, and most particularly contemporary culinary fiction relating life stories of women who migrated from the 
Middle East to Europe and North America. The author, who lectures in English at Tennessee Tech University, reveals and unpacks emblematic situations from sharing flavours and know-hows and explores the dynamics of multiculturalism using the tools of postcolonial literary criticism and cultural studies. The literature studied allows us to appreciate the role of food in exchanging with and learning from the Other on interpersonal and intimate levels.

The first section of the book titled "Strangers in a Strange Land" consists of three chapters that compare four novels and underlines the importance of spatial dynamics immobility and mobility, private and public - in the process of culinary diplomacy. The works studied, namely Marsha Mehran's Pomegranate Soup (2005) and Rosewater and Soda Bread (2008), Joanne Harris's Peaches for Monsieur Le Curé (2013) and Donia Bijan's The Last Days of Café Leila (2017), indicate the links that can be forged between different cultures based on food. The emblematic places of these four works are the Babylon Café established in rural Ireland by Iranian sisters who fled the Islamic revolution, the chocolate vending truck in one French village, the private space of a family from Morocco living near this village, and finally the Café Leila founded in Tehran by a returned émigré. Each novel highlights knowledge-specific culinary activities and the social dynamics they generate, from hospitality to hostility, in bi-denominational (i.e. Christian-Islamic) contexts. Gray's literary analyses are anchored in the spatial theory developed by Doreen Massey, notably Space, Place, and Gender (1994). Massey's notion of "territorialization" allows Gray to develop a holistic approach to space, in its social, symbolic, emotional dimension.

5 The second section "Writing with Gusto: The Gustemological in Culinary Fiction" is divided into three chapters and focuses on four books: Marsha Mehran's Pomegranate Soup (2005), Abu Jaber's Crescent (2003) and The Language of Baklava (2005), and Mama's Homesick Pie by Donia Bijan (2011). This second section explores the act of nourishing as an art of living and as an expression of identity, as well as other dimensions of food, such as food and heritage, food and memory, food and forgetfulness, food and intimate life. These different facets broaden the definition and understanding of culinary diplomacy. The trajectories of the characters in these stories, their families, and sentimental lives appear closely linked to culinary anecdotes, recipes or even gourmet moments, bridging cultures of origin and of adoption. Some of the characters are portrayed as in search of identity, dealing with multiple spatial and cultural affiliations (especially between the Near Eastern region and the American continent), which give the kitchen a fundamental role.

6 In her conclusion, the author contextualizes the need to highlight the fundamental role of culinary diplomacy, and the role of fictions in raising awareness about contemporary migrants, the richness they bring and hostilities they face. Her book offers an important corrective to reductive, exoticizing, and stereotypical representations of appreciation of foreign food as a sign of the cultural open-mindedness. The novels Gray analyses explore cuisine from the perspective of the several migrant generations. In a sense, this is a powerful way to deconstruct stereotypes about the other, especially concerning the Iranian sisters in Marsha Mehran's novel Pomegranate Soup and immigrants from Morocco in Joanne Harris's novel.

7 The numerous references mobilized by the author are well mastered and her state of the art is rich. Some references to French critical literature could have further enriched her demonstration, in particular Liban : Le vivre ensemble (2004) by Aïda Kanafani-Zahar, 
an anthropologist from Lebanon who has worked a lot on the concept of "livingtogether," the dynamics of sharing and demarcation that arise in the Lebanese context through the prism of a food reading. Claudia Roden's Le livre de la cuisine Juive (1996) cited in the introduction could have been taken up again, particularly in relation to the processes of preserving the culinary knowledge of Jewish societies and enriching them over time, through adaptation to host societies. Finally, taking from Appadurai's notion of "ethnoscape," the anthropologist Chantal Crenn proposed the notion of "foodscape" as "constructed places wherein food practices, values, meanings and representations intersect with the material and environmental realities." The concept of "foodscape" elaborated by Crenn amongst others would have constituted another fruitful entry point for the literature that Gray is reading.

\section{AUTHORS}

\section{SOPHIE-ANNE SAUVEGRAIN}

Sophie-Anne Sauvegrain has conducted research in food anthropology in the Mediterranean region for more than ten years, between Aleppo (IFPO, French Institute of the Middle East), Marseille (CNRS-Université de la Méditerranée) for her doctoral studies, and Montpellier (Supagro-Inra and Cirad) for her post-doctoral research. She is currently working for a company based in Normandy, France, specializing in the treatment of child malnutrition. Amongst her publications, "Fast foods et pratiques alimentaires des jeunes à Alep. Émancipation personnelle, marquage des territoires de groupes, politiques d'investissement ?" in Alep et ses territoires (2014) and "Cuisines et temps de partages à Alep" in the online journal of OCHA-Observatoire Cniel des Habitudes Alimentaires (2012, www.lemangeur-ocha.com). 